\title{
Kierrätyslannoitteet luomujäävuorisalaatin tuotannossa
}

\author{
Sari Iivonen ${ }^{1)}$, Tiina Tontti ${ }^{2)}$ ja Hanna Avikainen ${ }^{1)}$ \\ 1) Helsingin yliopisto, Ruralia-instituutti,Lönnrotinkatu 7, 50100 Mikkeli, sari.iivonen@helsinki.fi, \\ hanna.h.avikainen@helsinki.fi \\ ${ }^{2)}$ MTT, Kasvintuotannon tutkimus, Lönnrotinkatu 3, 50100 Mikkeli, tiina.tontti@mtt.fi
}

\section{Tiivistelmä}

Jäävuorisalaatin tuotannossa on sadontuoton turvaamiseksi huolehdittava riittävästä typpilannoituksesta ja ravinteiden oikea-aikaisesta vapautumisesta maasta. Jäävuorisalaatin luomutuotannossa on usein tarpeen hyödyntää viherlannoituksen lisäksi luomutuotannossa hyväksyttäviä lisälannoitteita tai maanparannustuotteita. Tutkimme kahtena peräkkäisenä kasvukautena 2010-2011 biokaasulaitosten käsittelyjäännösten, liha-luujauhon ja rakeistetun kananlannan käyttöä jäävuorisalaatin lannoitteena. Tarkastelussa olivat myös erilaiset viherlannoituskäytännöt yhdistettynä kierrätyslannoitteiden käytön kanssa. Kokeet toteutettiin MTT:n Karilan tutkimusaseman pelloilla Mikkelissä. Kesän 2010 kenttäkokeessa testasimme kahta erilaista biokaasulaitoksen käsittelyjäännöstä (A ja B) ja liha-luujauhoa (Erikoisviljo, Honkajoki Oy) ja vertasimme niitä kontrollina toimivaan NPK -lannoitukseen ja lannoittamattomiin ruutuihin. Käsittelyjäännös A oli peräisin biokaasulaitoksen pilottireaktorista, jossa prosessin syötteinä oli naudanlietelantaa, kananlantaa ja salaattijätteitä. Käsittelyjäännös B oli peräisin toiminnassa olevasta maatilamittakaavan biokaasulaitoksesta, jossa syötteinä oli käytetty naudan lietelantaa ja nurmirehua. Kesällä 2011 toteutetuissa kenttäkokeissa salaatti kasvatettiin koeruuduissa, joissa oli edellisenä kesänä kasvatettu esikasvina herne-kaura-seosta tai tuotantokasvina jäävuorisalaattia sekä molemmissa tapauksissa pyydyskasvina loppukesänä kylvettyä vehnää. Lannoitusvaihtoehtoina kesällä 2011 olivat käsittelyjäännös B, liha-luujauho ja kompostoitu kananlantarae sekä kontrollina NPK -lannoitus ja lannoittamaton käsittely. Sadonkorjuussa laskettiin salaattien kokonaisbiomassa ja kauppakelpoinen sato. Myös sadon laatua ja kasvitautien esiintymistä eri käsittelyissä arvioitiin. Ravinteiden vapautumista salaatin käyttöön eri lannoituskäsittelyissä arvioitiin salaatista vertaamalla typen käytön tehokkuutta eri käsittelyissä. Kesän 2010 kenttäkokeissa jäävuorisalaatin kauppakuntoinen kokonaissato eri lannoitekäsittelyissä oli keskimäärin $20000-24000$ kg/ha ja kesällä 2011 huomattavasti alhaisempi $7700-14000 \mathrm{~kg} / \mathrm{ha}$. Kasvattamalla ilmakehän typpeä sitovaa hernekauraseosta esikasvina saavutettiin hieman korkeammat satotasot kokonaissatotason vaihdellessa $11500-18300 \mathrm{~kg} / \mathrm{ha}$. Kierrätyslannoitteiden kokonaistyppeen suhteutettu kauppakuntoinen salaattisato oli samankaltainen erilaisista raaka-ainepohjista huolimatta. Kierrätyslannoitteista parhaimmat typen käytön tehokkuudet saavutettiin paljon liukoista typpeä (70 \% kokonaistypestä) sisältävällä käsittelyjäännöksellä. Yhtä suuren liukoisen typen määrän omaava käsittelyjäännös voi olla lannoitusvaikutukseltaan kanalantarakeen veroinen.

Asiasanat: jäävuorisalaatti, biokaasulaitoksen käsittelyjäännös, liha-luujauho, kananlantarae, satotaso, typen käytön tehokkuus 


\section{Johdanto}

Kierrätyslannoitteiden käyttö on osa suljetumpien ravinnekiertojen kehittämistä ja samalla kestävää kehitystä edistävää toimintaa. Kierrätyslannoitteiden hyödyntäminen ravinteiden saatavuuden kannalta vaateliaiden avomaanvihannesten tuotannossa on käytännön kannalta tärkeää, jotta voidaan monipuolistaa vaateliaiden kasvien lisälannoitusvaihtoehtoja. Viherlannoituksen, kerääjäkasvien ja perinteisten kompostien käytön lisäksi vihannesviljelyssä uusia lannoitusvaihtoehtoja ovat biokaasulaitoksista syntyvät käsittelyjäännökset. Niiden hyödyntäminen käytännössä vaatii kuitenkin vielä tutkimus- ja kehittämistoimintaa ennen kuin voidaan varmistaa niiden elintarviketurvallisuuden ja sadonmuodostuksen kannalta järkevä käyttö avomaanvihannestuotannossa. Luomulainsäädäntö asettaa vaatimuksia vihannesten lannoituskäytännöille rajaten sallittujen lannoitteiden ulkopuolelle tavanomaisesti tuotetut kemialliset lannoitteet. Luomuvihannestuotannossa on sallittua ja tarpeellista käyttää sadon tuottamiseen eloperäisiä lannoitteita kuten kompostoituja lantoja ravinteita sitovien esikasvien lisäksi.

Kierrätyslannoitteet sisältävät yleensä runsaasti orgaanista ainesta. Usein kierrätyslannoitteiden kokonaisravinnesisällöstä vain pieni osa on heti kasvien käytettävässä muodossa (esim. maanparannuskompostit), jolloin ne vaativat kasvinviljelykäytössä liukoisen typen täydennystä (Tontti ym. 2009). Toisaalta joillakin kierrätyslannoitteilla (esim. lietemäiset mädätysjäännökset) voi liukoisen typen pitoisuus olla samaa luokkaa lietelannan kanssa, jolloin levityksen jälkeisen typen haihdunnan ehkäiseminen on tärkeää. Kokeellista tutkimusta on lantapohjaisten käsittelyjäännösten lannoituskäytöstä tehty Suomessa hyvin vähän. Joitakin tutkimuksia on viime aikoina tehty käsittelyjäännösten lannoitusvaikutusten selvittämiseksi ohralla ja nurmella (Kapuinen ym. 2008a,b).

Tämän tutkimuksen tavoitteena oli erilaisen raaka-ainepohjan omaavien biokaasulaitosten käsittelyjäännösten lannoitusvaikutusta jäävuorisalaatilla ja verrata lannoitusvaikutusta liha-luujauhoon, kompostoituun kananlantarakeeseen ja kemialliseen NPK -lannoitteeseen. Tutkimuksessa selvitettiin myös viljelykierron vaikutusta kierrätysravinteiden hyödyntämiseen luomutuotannossa.

\section{Aineisto ja menetelmät}

\section{Kenttäkokeet ja lannoitus}

Toteutimme kesällä 2010 kenttäkokeen, jossa testasimme kahta erilaista biokaasulaitoksen käsittelyjäännöstä (A ja B) ja liha-luujauhoa (Erikoisviljo, Honkajoki Oy) ja vertasimme niitä kontrollina toimivaan NPK -lannoitukseen (Kloorivapaa Y1, N 80, P 50, K 190) ja lannoittamattomiin ruutuihin. Koejärjestely oli satunnaistettujen lohkojen koe, jossa toistojen määrä oli neljä. Koeruudun koko oli 8 $\mathrm{m}^{2}$. Käsittelyjäännös A oli peräisin biokaasulaitoksen pilottireaktorista, jossa prosessin syötteinä oli naudanlietelantaa, kananlantaa ja salaattijätteitä. Käsittelyjäännös B oli peräisin toiminnassa olevasta maatilamittakaavan biokaasulaitoksesta, jossa syötteinä oli käytetty naudan lietelantaa ja nurmirehua. Käsittelyjäännöksissä annettava liukoisen typen määrä vakioitiin kyseisestä erästä analysoitujen ennakkotietojen perusteella. Annostelulla tavoiteltiin $120 \mathrm{~kg}: n$ liukoisen typen annettua määrää (Taulukko 1.). Liha-luujauhon annostelu rajattiin kuitenkin nitraattisäädöksen mukaiseen kokonaistypen suurimpaan sallittuun käyttömäärään. Kaikki lannoitteet levitettiin pellon pintaan kaksi viikkoa ennen salaatin taimien istutusta, jotta orgaaniset lannoitukset saivat kypsyä maassa ja ravinteiden liukeneminen saattoi alkaa. Neljän tunnin kuluessa lannoitteiden pintalevityksestä koealue muokattiin kevyesti joustopiikkiäkeellä. Lisälannoitusta ei annettu kasvukauden aikana missään käsittelyssä. Jäävuorisalaatin lajikkeena oli Brenson ja koe toteutettiin 1.6.-23.7. välisenä ajanjaksona, jolloin kauppakelpoisen sadon saavuttamiseen tarvittiin koeolosuhteissa 53 vrk. Sadonkorjuun jälkeen kerääjäkasviksi kylvettiin vehnä, joka muokattiin maahan kesäkuussa 2011.

Kesällä 2011 toistettiin salaatin lannoituskoe samoilla koeruuduilla lannoituskäsittelyinä käsittelyjäännös B, liha-luujauho, kompostoitu kananlantarae (Biolan 4-1-2) käsittelyjäännös A:n sijaan ja kontrolleina olivat NPK ja lannoittamaton ruutu. Vastaava lannoituskäsittely toteutettiin myös ruuduilla, joissa oli edellisenä kesänä kasvatettu esikasvina herne-kauraseosta ilman lisälannoitusta. Luonnonmukaisesti kasvatetut salaatin taimet (lajike Diamantinas) istutettiin 29.-30.6. ja sato korjattiin 17.-18.8. Vuonna 2011 liukoisen typen tavoitetasoksi asetettiin orgaanisilla lannoitteilla $70 \mathrm{~kg}$ liukoista N ja NPK:lla $120 \mathrm{~kg}$ liukoista N. NPK annosteltiin kahdessa erässä, $80 \mathrm{~kg}$ N kokeen alussa ja $40 \mathrm{~kg}$ $\mathrm{N}$ kastelulannoituksena salaattien kerimisen alussa. Tällä simuloitiin lannoituskäsittelyä tavanomaises- 
sa salaattituotannossa. Niihin ruutuihin, joissa oli vuonna 2010 kasvatettu typpeä sitovaa herne-kauraesikasviseosta, annosteltiin $30 \mathrm{~kg}$ vähemmän kokonaistyppeä kuin ruutuihin, joissa kasvatettiin toista peräkkäistä salaattisatoa.

Taulukko 1. Kokeessa käytetyt ravinnemäärät $(\mathrm{kg} / \mathrm{ha})$ eriteltyinä annetun typen $(\mathrm{N})$, fosforin $(\mathrm{P})$ ja kaliumin $(\mathrm{K})$ suhteen eri lannoituskäsittelyissä. Lannoitteiden ravinneanalyysit on tehty levityksen yhteydessä otetuista näytteistä.

\begin{tabular}{|l|l|l|l|l|l|}
\hline Lannoituskäsittely & $\begin{array}{l}\text { Liukoinen N } \\
\text { (kg/ha) }\end{array}$ & $\begin{array}{l}\text { Kokonais-N } \\
\text { (kg/ha) }\end{array}$ & $\begin{array}{l}\text { Liukoisen typen } \\
\text { osuus kokonais- } \\
\text { typestä, \% }\end{array}$ & $\begin{array}{l}\text { Kokonais- } \\
\mathbf{P}(\mathbf{k g} / \mathbf{h a})\end{array}$ & $\begin{array}{l}\text { Kokonais - } \\
\text { K } \\
\text { (kg/ha) }\end{array}$ \\
\hline Salaattikoe 2010 & & & & & \\
\hline Kontrolli & 0 & 0 & 0 & 0 & 0 \\
\hline Käsittelyjäännös A & 104 & 148 & 70 & 34 & 80 \\
\hline Käsittelyjäännös B & 109 & 200 & 55 & 41 & 227 \\
\hline Liha-luujauho & 73 & 235 & 31 & 118 & 235 \\
\hline NPK & 80 & 80 & 100 & 50 & 190 \\
\hline $\begin{array}{l}\text { Salaattikoe 2011 } \\
\text { 2. salaattisato }\end{array}$ & & & & & \\
\hline Kontrolli & 0 & 0 & 0 & 0 & 0 \\
\hline Rakeistettu kananlanta & 70 & 140 & 50 & 42 & 70 \\
\hline Käsittelyjäännös B & 69 & 138 & 50 & 27 & 147 \\
\hline Liha-luujauho & 38 & 120 & 32 & 60 & 120 \\
\hline NPK & 120 & 120 & 100 & 50 & 190 \\
\hline $\begin{array}{l}\text { Salaattikoe 2011 } \\
\text { esikasvina herne- } \\
\text { kaura }\end{array}$ & & & & & \\
\hline Kontrolli & 0 & & & 0 & \\
\hline Rakeistettu kananlanta & 55 & 0 & 0 & 0 & 0 \\
\hline Käsittelyjäännös B & 55 & 110 & 50 & 33 & 55 \\
\hline Liha-luujauho & 28 & 110 & 50 & 21 & 116 \\
\hline NPK & 90 & 90 & 31 & 45 & 90 \\
\hline & & 100 & 44 & 166 \\
\hline
\end{tabular}

\section{Satotaso ja typen käytön tehokkuus}

Jokaiselle koeruudulle istutettiin 63 salaatin tainta 3 riviin. Sadonkorjuu ajoittui hetkeen, jolloin taimien arvioitiin saavuttaneen kauppakelpoisen koon. Sadonkorjuussa ruudun keskimmäisen rivin taimista (n=21 v. 2010 ja n=16 v. 2011) arvioitiin kerien laatu, punnittiin kauppakunnostetun kerän paino ja taimet luokiteltiin alle $300 \mathrm{~g}$ painaviin keriin ja yli $300 \mathrm{~g}$ painaviin keriin. Tautien ja tuholaisten vioittamat ja muusta syystä laatuvialliset kerät hylättiin kokonaan.

Kokonaisbiomassan määritykset tehtiin systemaattisesti kuudesta taimesta/ruutu valitsemalla taimet ruutujen keskimmäisistä riveistä. Kerät, joiden kokonaisbiomassa oli määritetty, pilkottiin ja pilkottua salaattia kuivattiin $48 \mathrm{~h} 60{ }^{\circ} \mathrm{C}: s s a$. Taimien kuiva-aine määritettiin, jonka jälkeen kuivattu näyte jauhettiin ja yhdistettiin yhdeksi näytteeksi niistä tehtävää kokonaistyppianalyysiä varten. Ty-pen käytön tehokkuutta eri käsittelyissä laskettiin kaavalla:

Typen käytön tehokkuus $\%=100 \times\left(\left(\mathrm{X}_{\mathrm{f}}-\mathrm{X}_{0}\right) / \mathrm{X}_{\mathrm{r}}\right)$,

jossa $\mathrm{X}_{\mathrm{f}}=$ salaattibiomassan $\mathrm{N}$ saanto $(\mathrm{kg} / \mathrm{ha})$ lannoitetussa ruudussa,

$\mathrm{X}_{0}=$ salaattibiomassan $\mathrm{N}$ saanto lannoittamattomassa ruudussa $(\mathrm{kg} / \mathrm{ha}) \mathrm{ja}$

$\mathrm{X}_{\mathrm{r}}=$ kasvukauden aikana annettu kokonaistypen määrä $(\mathrm{kg} / \mathrm{ha})$. 


\section{Tulokset ja tulosten tarkastelu}

Jäävuorisalaatin kokonaissato eri lannoitekäsittelyissä oli keskimäärin 20000 - $24000 \mathrm{~kg} / \mathrm{ha}$ vuonna 2010 (Kuva 1). Koon perusteella kauppakelpoiseksi luokitellun sadon osuus oli käsittelyjäännöksillä lannoitettaessa keskimäärin $74 \%$, liha-luujauholla $82 \%$ ja NPK -ruuduissa keskimäärin $64 \%$. NPK lannoitetun salaatin pieni kauppakelpoisen sadon osuus johtui niukasta lannoitetypen määrästä. Selkeästi suuremman kokonaistyppimäärän kierrätyslannoitteista (148-235 kg kok N/ha) saaneet salaattisadot olivat kuitenkin vain samalla tasolla kuin NPK -lannoitteella $(80 \mathrm{~kg} \mathrm{~N} / \mathrm{ha})$ tuotettu sato.

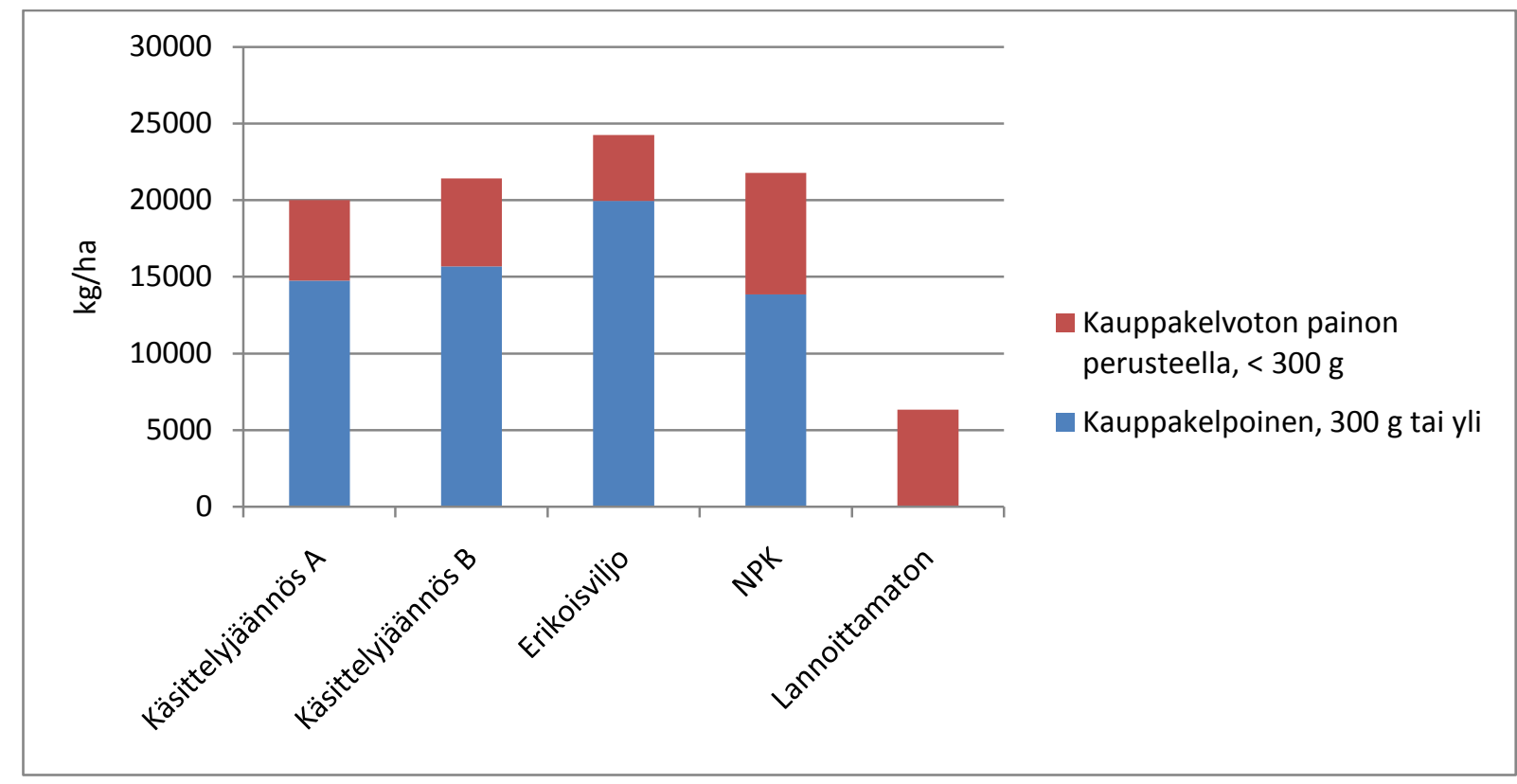

Kuva 1. Kauppakuntoisen salaattisadon määrä (kg/ha) kasvukaudella 2010. Kauppakuntoiseksi luokiteltu sato on jaoteltuna koon perusteella kauppakelpoiseen ja kauppakelvottomaan luokkaan.

Vuonna 2011 kauppakuntoiset satotasot jäivät selkeästi alhaisemmiksi vaihdellen 7700 - $14000 \mathrm{~kg} / \mathrm{ha}$ niissä lisälannoitetuissa ruuduissa, joissa edellisenä kesänä kasvoi jäävuorisalaattia (Kuva 2). Ruuduissa, joissa oli edellisenä kesänä kasvatettu ilmakehän typpeä sitovaa herne-kauraseosta saavutettiin hieman korkeammat satotasot kokonaissatotason vaihdellessa $11500-18300 \mathrm{~kg} / \mathrm{ha}$. Ruutujen välinen hajonta oli kuitenkin niin suurta, että esikasvivaikutus ei ole tilastollisesti merkitsevä. Alhaista satotasoa voi selittää lajikevalinta. Samana kasvukautena toteutetuissa tilakokeissa Diamantinas -lajike osoittautui satotasoltaan heikoimmaksi testatuista luomujäävuorisalaattilajikkeista. 


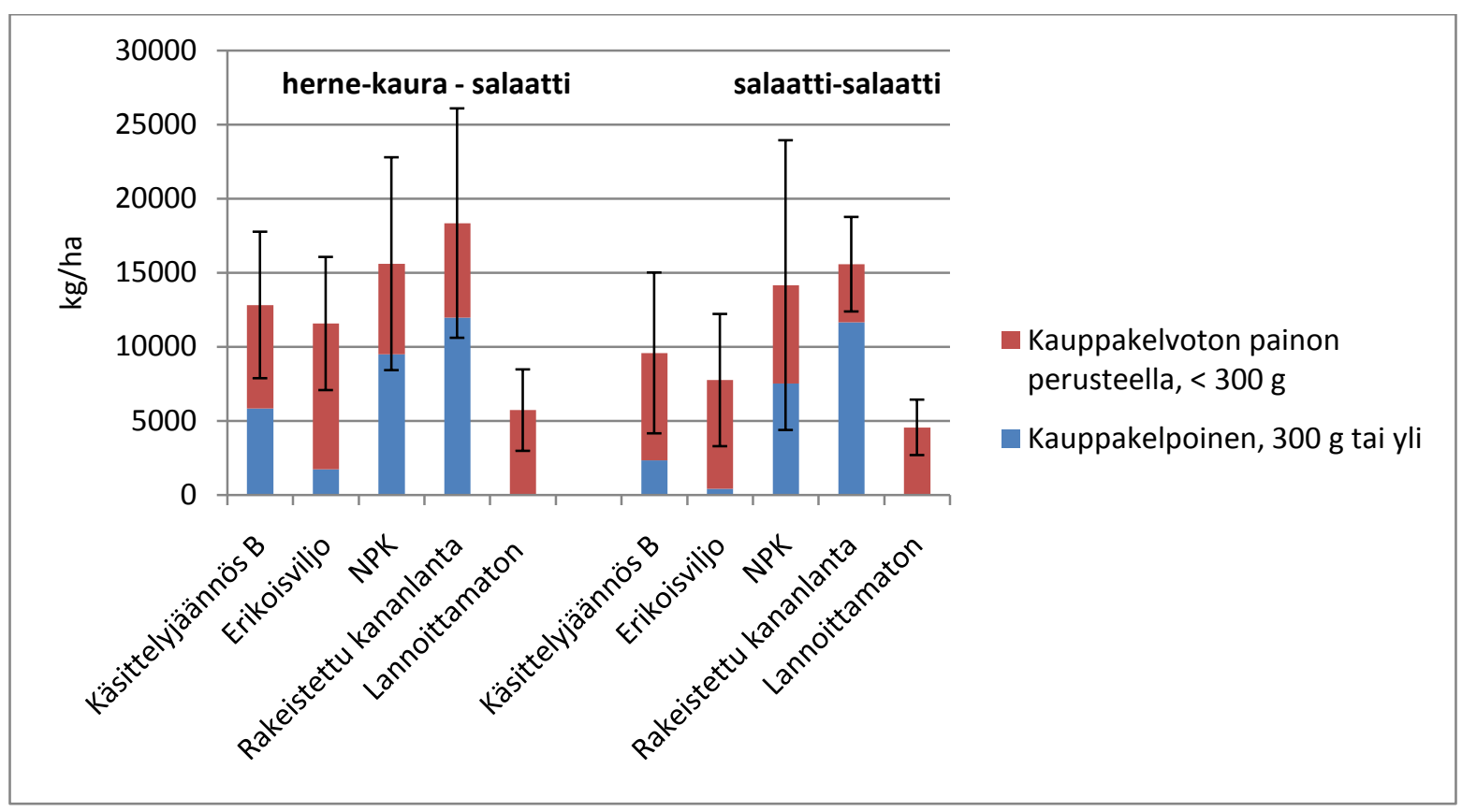

Kuva 2. Kauppakuntoisen salaatin sato (kg/ha) kasvukaudella 2011 esikasvi-lannoituskäsittelyissä ja lannoituskäsittelyissä, joissa kasvatettiin toinen salaattisato peräkkäin. Pylväs kuvaa neljän ruudun keskiarvoa ja jana koko kauppakuntoisen sadon keskihajontaa.

Vuonna 2011 kasvukausi oli Etelä-Savossa olosuhteiltaan haastava jäävuorisalaatin viljelyn kannalta ja huomattava osa sadosta menetettiin salaatin piilomädän (Pseudomonas cichorii) aiheuttamien vaurioiden ja muiden laatuvikojen takia. Tarkasteltaessa koon ja muun ulkoisen laadun perusteella kauppakelpoista satoa (300 g tai yli), saatiin vuonna 2011 rakeistetulla kananlannalla suurin sato, joka oli merkitsevästi suurempi kuin lannoittamattomissa ruuduissa (Kuva 2). Tulos viittaa siihen, että alhaisesta vesiliukoisen typen määrästä huolimatta, kananlantarakeesta irtoaa hyvin ravinteita kasvukauden aikana salaatin käyttöön. Orgaanisista lannoitteista heikoin lannoitusvaikutukseltaan oli liha-luujauho. Liha-luujauholla lannoitetuissa ruuduissa suuri pienten kerien $(<300 \mathrm{~g})$ osuus kauppakuntoisesta sadosta viittaa siihen, että ravinteita ei ole vapautunut riittävän nopeasti salaatin käyttöön kerimisvaiheessa. Vuonna 2011 liha-luujauhon sisältämä kokonaistypen määrä oli vain $38 \%$ edellisenä vuonna annostelusta liha-luujauhon kokonaistypestä. Vuoden 2011 lannoitustaso 1100-1600 kg Erikoisviljoa hehtaarille on jäävuorisalaatille liian alhainen lisälannoitustaso, sillä kauppakelpoisen sadon määrä jäi hyvin alhaiseksi. Liha-luujauhon heikko lannoitusvaikutus kokeessa voi johtua rakeistetun Erikoisviljon käytöstä. Tähän viittaa se, että samana kesänä toteutetussa saman Diamantinas -salaattilajikkeen lannoituskokeessa hienojakoisella Aitoviljolla lannoitettaessa (1500 kg/ha eli $120 \mathrm{~kg} \mathrm{Kok.N/ha)} \mathrm{saa-}$ tiin kauppakelpoista satoa noin $13000 \mathrm{~kg} / \mathrm{ha}$. Huomattavaa on myös se, että ilman lisälannoitusta kauppakelpoista satoa ei saatu lainkaan, vaikka koe toteutettiin luomukierrossa olevalla pellolla.

Koska eloperäisten tuotteiden mukana annetut ravinnemäärät vaihtelivat tasaisesta annostelutavoitteesta huolimatta, on lannoitekäsittelyjen vertailtavuuden kannalta järkevää verrata satoja annetun kokonaistypen suhteen (Kuva 3). Tämä tunnus luku kuvaa myös sitä kuinka paljon kauppakelpoista satoa saadaan annettua kokonaistyppipanosta kohden. Tässä vertailussa jäävuorisalaatin kokonaissato oli vuonna 2010 annettua kokonaistyppikiloa kohden selvästi suurin NPK -lannoitetuissa käsittelyissä, mikä kuvaa lannoitteen sisältämän typen hyvää käyttökelpoisuutta kasvien sadonmuodostuksen kannalta. Kierrätyslannoitteiden kokonaistyppeen suhteutettu salaattisato oli samankaltainen erilaisista raaka-ainepohjista huolimatta vuonna 2010. Vuonna 2011 rakeistettu kananlanta, käsittelyjäännös B ja liha-luujauho eivät eronneet merkitsevästi toisistaan, vaikka kananlantakäsittelyssä keskimääräinen satotaso oli hieman suurempi. Typen käytön tehokkuutta tarkasteltiin myös salaatin maanpäälliseen kuivamassan sisältämän typen määrän avulla. Typen käytön tehokkuus oli vuonna 2010 suurin, noin 23 \% käsittelyjäännös A:lla (Kuva 4). Käsittelyjäännöksellä B typen käytön tehokkuus oli huomattavasti alhaisempi, vain noin $10 \%$, mikä johtuu sen selvästi alhaisemmasta liukoisen typen osuudesta 
(55\%) verrattuna käsittelyjäännös A:han (70\%). Vuonna 2011 toteutetussa kokeessa kananlantarakeessa ja käsittelyjäännös B:ssä olivat kokonaistypen määrät ja kokonaistypen ja liukoisen typen suhteet samanlaisia. Kun verrattiin samanlaisen esikasvikäsittelyn tilannetta, saatiin käsittelyjäännös B:llä ja kananlantarakeella samankaltaiset typen käytön tehokkuudet, 17-18\%. Verrattaessa 2. peräkkäisen salaattisadon tilannetta, typen käytön tehokkuus kananlantarakeella lannoitettaessa oli selvästi suurempi kuin esikasviruuduissa. Tämä viittaa siihen, että edellisenä kesänä kananlantaruuduille annetun käsittelyjäännös A:n sisältämiä ravinteita oli vielä kasvien käytettävissä seuraavana kasvukautena.

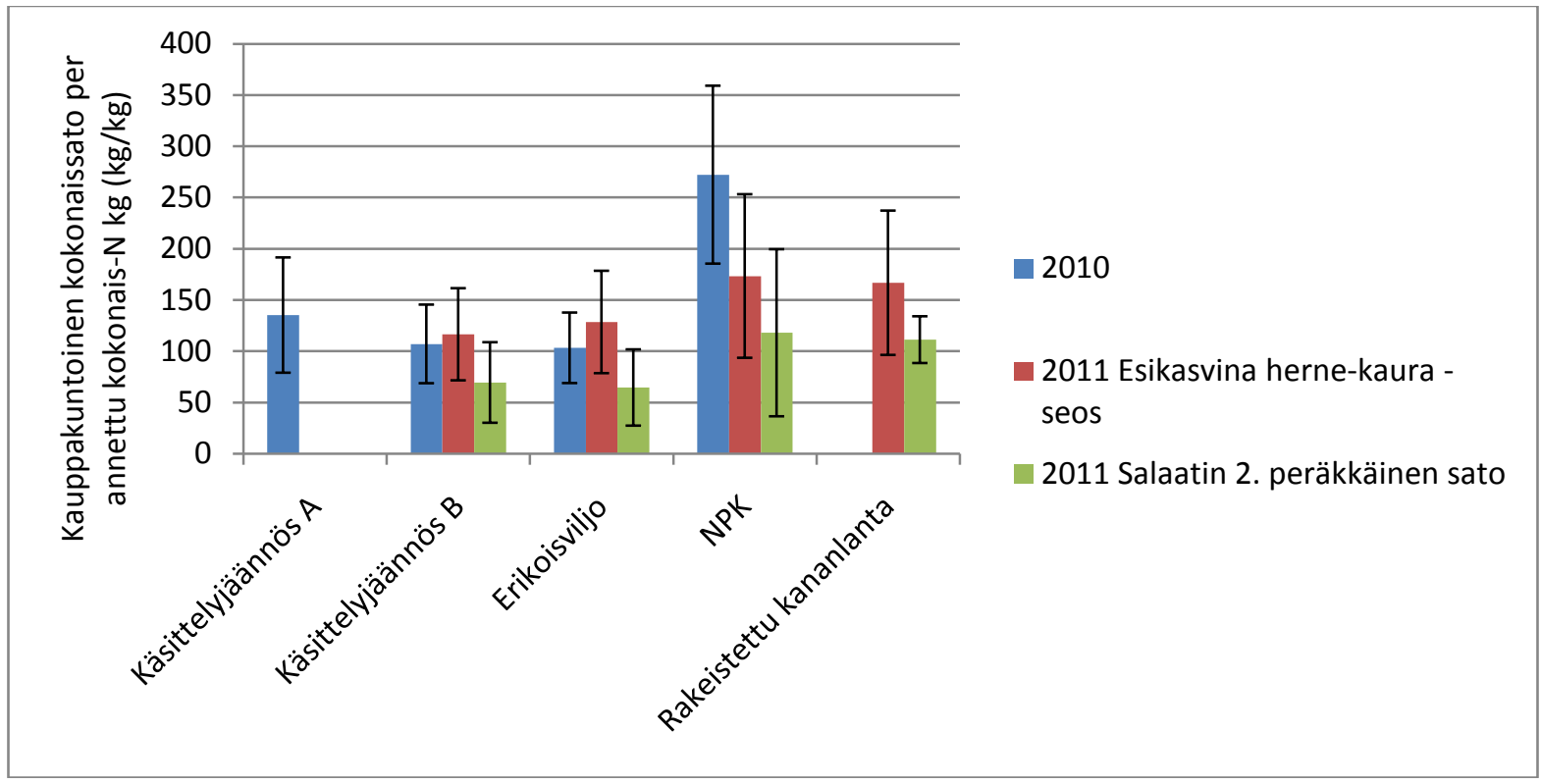

Kuva 3. Jäävuorisalaatin kauppakuntoinen kokonaissato annettua kokonaistyppikiloa kohden. Pylväs kuvaa neljän ruudun keskiarvoa ja jana keskihajontaa.

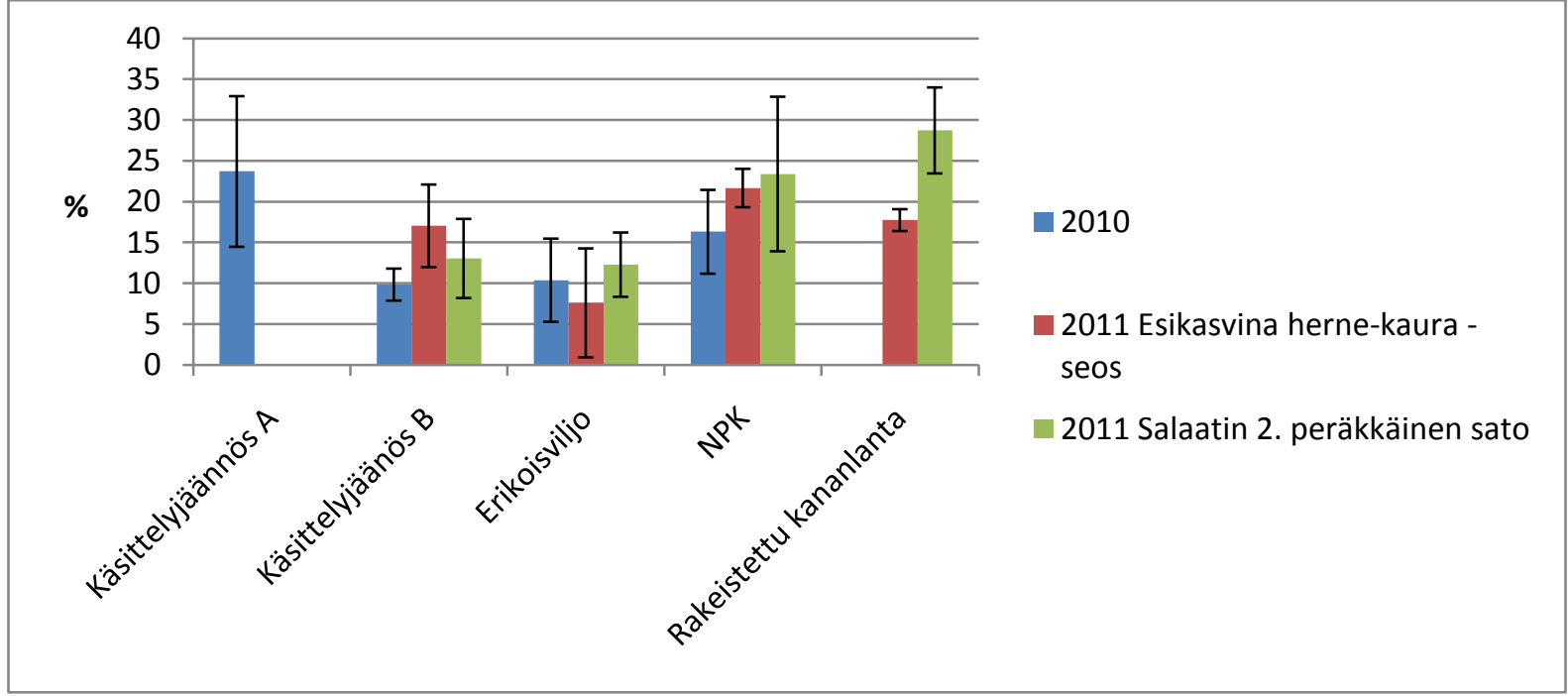

Kuva 4. Typen käytön tehokkuus eri lannoituskäsittelyissä. Pylväs kuvaa neljän ruudun keskiarvoa ja jana keskihajontaa. 


\section{Johtopäätökset}

Kierrätyslannoitteilla saavutetaan korkeita satotasoja, mutta vain selvästi korkeammilla kokonaistyppipanoksilla kuin kemiallisilla lannoitteilla. Kokeessa on nähtävissä viitteitä siitä, että satotasoon voidaan vaikuttaa positiivisesti esikasvilla. Käsittelyjäännösten lannoitusvaikutukseen vaikuttaa selvästi niiden sisältämän typen liukoisuus. Kun liukoisen typen osuus oli $70 \%$ kokonaistypestä, saavutettiin selvästi korkeampi typen käytön tehokkuus kuin $55 \%$ :n liukoisen typen osuudella. Käsittelyjäännösten raaka-ainepohjalla onkin vaikutusta niiden lannoitustehoon. Jäävuorisalaatin lannoitteena käsittelyjäännökset ovat samanveroisia kuin kananlantarae ja raaka-ainepohjasta riippuen parempia kuin rakeistettu liha-luujauho.

\section{Kirjallisuus}

Kapuinen, P., Perälä, P., Regina, K. 2008a. Mädätyksen vaikutus naudan lietelannan lannoitusominaisuuksiin nurmella. Teoksessa: Leena Rantamäki-Lahtinen (toim.) Maataloustieteen Päivät 2008 10.-11.1.2008, Viikki, Helsinki: esitelmä- ja posteritiivistelmät. Suomen maataloustieteellisen seuran tiedote 24: 65.

Kapuinen, P., Perälä, P., Regina, K. 2008b. Mädätyksen vaikutus sian lietelannan lannoitusominaisuuksiin ohralla. Teoksessa: Leena Rantamäki-Lahtinen (toim.) Maataloustieteen Päivät 2008 10.-11.1.2008, Viikki, Helsinki: esitelmä- ja posteritiivistelmät. Suomen maataloustieteellisen seuran tiedote 24: 243.

Tontti, T., Nykänen, A. \& Kuisma, M. 2009. Waste composts as nitrogen fertilizers for forage leys. Agricultural and Food Science 18: 57-75. 